factors, i.e. smoking history (6.3\% vs $38.4 \%$ ), hypertension (10.4\% vs $30.5 \%$ ) and diabetes $(12.5 \%$ vs $17.9 \%)$. Instead these patients had more upper respiratory inflammations (chronic sinusitis, chronic otitis media and allergic rhinitis, $33.3 \%$ vs $6.6 \%$ ) before the disease onset.

Conclusions: We found that MPA had more atherosclerotic risk factors, and MPOGPA had more upper respiratory inflammations. These factors may determine MPA or GPA phenotypes in MPO-ANCA positive AAV.

References:

[1] Ono N at al. Characteristics of MPO-ANCA-positive granulomatosis with polyangiitis: a retrospective multi-center study in Japan. Rheumatol Int. 2015 Mar;35(3):555-9.

[2] Miloslavsky EM et al. MPO-ANCA-Positive and ANCA-Negative Patients With Granulomatosis With Polyangiitis (Wegener's): Distinct Patient Subsets. Arthritis Rheumatol. 2016 Dec;68(12):2945-2952.

[3] Schirmer JH at al. MPO-ANCA-Positive Granulomatosis With Polyangiitis (Wegener's) Is a Clinically Distinct Subset of ANCA-Associated Vasculitis: A Retrospective Analysis of 315 Patients From a German Vasculitis Referral Center. Arthritis Rheumatol. 2016 Dec;68(12):2953-2963.

Acknowledgements: We gratefully acknowledge the work of people who helped to correct patients data.

Disclosure of Interest: None declared

DOI: 10.1136/annrheumdis-2017-eular.2839

\section{AB0583 DIFFERENCES BETWEEN ISOLATED AORTITIS AND NON-INFECTIOUS AORTITIS SECONDARY TO OTHER ENTITIES. STUDY OF 93 PATIENTS FROM A SINGLE CENTER}

N. Vegas-Revenga ${ }^{1}$, J. Loricera ${ }^{1}$, D. Prieto-Peña ${ }^{1}$, J.L. Hernández ${ }^{2}$,

I. Martínez-Rodríguez ${ }^{3}$, J.I. Banzo ${ }^{3}$, M. Calderón-Goercke ${ }^{1}$, V. Calvo-Río ${ }^{1}$, L.C. Domínguez-Casas ${ }^{1}$, C. González-Vela ${ }^{4}$, P. Fuentevilla ${ }^{1}$,

M.Á. González-Gay ${ }^{1}$, R. Blanco ${ }^{1} .{ }^{1}$ Rheumatology; ${ }^{2}$ Internal Medicine; ${ }^{3}$ Nuclear Medicine; ${ }^{4}$ Pathology, Hospital Universitario Marqués de Valdecilla. IDIVAL, Santander, Spain

Background: Non-infectious aortitis is an inflammation of aortic wall which may be isolated or associated with a cluster of diseases.

Objectives: Our aim was to compare the clinical and laboratory findings of patients with isolated aortitis and patients with aortitis secondary to other underlying conditions.

Methods: Retrospective study of 93 patients with non-infectious aortitis diagnosed by PET/CT scan from a referral center from January 2010 to December 2016. We have considered two groups: group a) isolated aortitis; and group b) secondary aortitis. Distributions of categorical variables were compared by the Pearson $\mathrm{Chi}^{2}$ or Fisher exact test. Quantitative variables were analyzing using the Student $t$ test or Mann-Whitney $U$ test as appropriate.

Results: Ninety-three patients were diagnosed with non-infectious aortitis. One patient was excluded due to missing data. Group a) was composed by 54 patients (34 women/ 20 men) with a mean age of $67 \pm 11$ years; group b) comprised 38 patients (28 women/ 10 men) with a mean age of $68 \pm 11$ years. In this group, the underlying conditions we found were: giant cell arteritis $(n=24)$, Takayasu arteritis $(n=3)$, spondiloarthropathy $(n=3)$, Sjögren's syndrome $(n=3)$, ulcerative colitis $(n=2)$, sarcoidosis $(n=1)$, rheumatoid arthritis $(n=1)$, polyarteritis nodosa $(n=1)$. The comparative study between both groups is shown in the TABLE. Only inflammatory low back pain and polymyalgic syndrome yielded statistical signification.

\begin{tabular}{|c|c|c|c|}
\hline Variables & $\begin{array}{c}\text { Group a } \\
\text { (isolated aortitis) } \\
n=54\end{array}$ & $\begin{array}{c}\text { Group b } \\
\text { (secondary aortitis) } \\
n=38\end{array}$ & p \\
\hline Ago (years), meant $S D$ & $67.2 \pm 11.1$ & $68.0 \pm 11.2$ & 0.73 \\
\hline$A(g e=70$ yoars. $n(\%)$ & $21(38.9)$ & $18(47.4)$ & 0.42 \\
\hline $\operatorname{sex}(M M), n$ & $20 / 34$ & $10 / 28$ & 0.28 \\
\hline Time from symptoms onset to PET date, median [IOR] & $12.5[3-36]$ & $19.5[6-75.5]$ & 0.29 \\
\hline \multicolumn{4}{|l|}{ Symptoms at the time of requesting PET } \\
\hline - Constitutional symptoms, $n$ (\%) & $15(27.8)$ & $14(36.8)$ & 0.24 \\
\hline - Fover, $n(0)$ & $7(13,0)$ & $11(28.9)$ & 0.06 \\
\hline - Infammatory low back pain., $n$ (\%) & $23(42.6)$ & $7(18.4)$ & 0.015 \\
\hline - Lower limb pain, $n$ (96) & $29(53.7)$ & $13(34.2)$ & 0.07 \\
\hline - Polymyalgic syndrome, $n$ (\%) & $40(74.1)$ & $18(47.4)$ & 0.016 \\
\hline - Headache, $n(\%)$ & $7(13.0)$ & $11(28.9)$ & 0.06 \\
\hline \multicolumn{4}{|l|}{ Laboratory values at the time of requesting PET } \\
\hline - Anaomia, $n(\%)$ & $8(14.8)$ & $10(26.3)$ & 0.16 \\
\hline -ESR $(m m / 1=n)$, mean $\pm S O$ & $44.7 \pm 31.6$ & $42,1 \pm 38.3$ & 0.42 \\
\hline - CRP (modl), median [IOR] & $0.9[0.6-2.3]$ & $0.9[0.2-2.6]$ & 0.76 \\
\hline \multicolumn{4}{|l|}{ Treatment at the time of requesting PET } \\
\hline - Pationts on corticostoroids. $n$ (\%) & $25(46.3)$ & $23(60.5)$ & 0.18 \\
\hline - Prednisone dose (mg). median IIORI & $10[5-10]$ & $10[7.5-16.97$ & 0.05 \\
\hline - Patients on traditional is agents, $n$ (\%) & $4(7.4)$ & $7(18.4)$ & 0.11 \\
\hline
\end{tabular}

Conclusions: In this study, we observed that both the presence of inflammatory low back pain and polymyalgic syndrome might have clinical relevance in the clinical suspicion of primary aortitis. However, larger studies are needed to corroborate these findings.

Disclosure of Interest: None declared

DOI: 10.1136/annrheumdis-2017-eular.3233

\section{AB0584 UTILITY OF PET/CT SCAN FOR THE DIAGNOSIS OF AORTITIS. A STUDY OF 170 PATIENTS FROM A SINGLE CENTER IN A 6-YEAR PERIOD}

N. Vegas-Revenga ${ }^{1}$, J. Loricera $^{1}$, D. Prieto-Peña ${ }^{1}$, I. Martínez-Rodríguez ${ }^{2}$, J.I. Banzo ${ }^{2}$, M. Calderón-Goercke ${ }^{1}$, V. Calvo-Río ${ }^{1}$, C. González-Vela ${ }^{3}$, J. González-Vela ${ }^{1}$, M.Á. González-Gay ${ }^{1}$, J.L. Hernández ${ }^{4}$, R. Blanco ${ }^{1}$. ${ }^{1}$ Rheumatology; ${ }^{2}$ Nuclear Medicine; ${ }^{3}$ Pathology; ${ }^{4}$ Internal Medicine, Hospital Universitario Marqués de Valdecilla. IDIVAL, Santander, Spain

Background: Aortitis is the inflammation of the aortic wall. This entity is often under-recognised due to its frequent presentation with non-specific symptoms. PET/CT scan represent a major breakthrough to establish an early diagnosis, but this is an expensive technique.

Objectives: Our aim was to compare the baseline characteristics of patients with a suspicion of aortitis and positive results on PET/CT scan, and those with a negative result, in order to search for predictive factors, that improve the clinical probability of diagnosis aortitis by this imaging technique.

Methods: Retrospective study on 170 patients and PET/CT scans ordered by suspicion of aortitis from a referral center from January 2010 to December 2016. According to a pre-specified protocol, the baseline epidemiological and clinical variables of patients with positive and negative PET/CT scans results for aortitis were reviewed. Distributions of categorical variables were compared by the Pearson $\mathrm{Chi}^{2}$ or Fisher exact test. Quantitative variables were analyzing using the Student $t$ test or Mann-Whitney $\mathrm{U}$ test as appropriate.

Results: In 170 patients, PET/CT scans were performed due to clinical suspicion of aortitis, and were positive in $93(54.7 \%)$ cases. Patients (113 women/57 men) had a mean age of $67.7 \pm 13.1$ years (range, $20-90$ years). One patient was excluded because missing clinical or laboratory data.

The underlying diseases at the moment of ordering the PET/CT scan were: giant cell arteritis (GCA) $(n=28)$, spondiloarthropaties $(n=7)$, conectivopaties $(n=6)$, Takayasu arteritis $(n=3)$, ulcerative colitis $(n=3)$, other condition $(n=11)$. The remaining 111 patients did not have any underlying condition suggestive of aortitis. Two out of 170 patients suspected an infectious aortitis (Brucella and Salmonella); however, PET/CT was negative in both cases.

Characteristics of patients with positive and negative $\mathrm{PET} / \mathrm{CT}$ scans were summarized in the Table. Patients with GCA had a higher percentage of positive PET/CT scans, whereas they were negative more frequently in patients who did not have any condition suggestive of underlying aortitis. Only inflammatory low back pain and polymyalgic syndrome were significantly more frequent in patients with positive PET/CT scans. The remaining clinical and laboratory variables did not show differences between both groups.

\begin{tabular}{|c|c|c|c|}
\hline & $\begin{array}{l}\text { Positivo PET } \\
n=92\end{array}$ & $\begin{array}{l}\text { Negative PET } \\
n=77\end{array}$ & $\mathbf{p}$ \\
\hline Age (years), moantSO & $67.4 \pm 11.1$ & $68.1 \pm 15.2$ & 0.73 \\
\hline$A g e \geq 70$ years, $n(\%)$ & $39(41.9)$ & $41(53.2)$ & 0.14 \\
\hline Sex (women), $n(\%)$ & $62(67.4)$ & $54(70.1)$ & 0.63 \\
\hline \multicolumn{4}{|l|}{ Underlying condition } \\
\hline - Giant coll artoritis, $n(\%)$ & $24(26.1)$ & $4(5.2)$ & 0.0002 \\
\hline - Takayasu artoritis, $n(\%)$ & $3(3.3)$ & $o(0)$ & 0.31 \\
\hline - Ulcorative colitis, $n$ (\%) & $2(2.2)$ & $1(1.3)$ & 0.87 \\
\hline - Conectivopaties, $n(\%)$ & $3(3.3)$ & $3(3.9)$ & 0.86 \\
\hline - Spondiloarthropatios, $n(\%)$ & $3(3.3)$ & $4(5.2)$ & 0.79 \\
\hline - None, $n(\%)$ & $54(58.7)$ & $57(74.0)$ & 0.03 \\
\hline - Other, $n(\%)$ & $3(3.3)$ & $8(10.4)$ & 0.11 \\
\hline \multicolumn{4}{|l|}{ Symptoms at the time of requesting PET } \\
\hline - Constitutional syndrome, $n(\%)$ & $30(32.6)$ & $36(46.8)$ & 0.06 \\
\hline - Fover, $n(\%)$ & $18(19.6)$ & $15(19.5)$ & 0.98 \\
\hline - Inflammatary low back pain, $n(\%)$ & $30(32.6)$ & $14(18.2)$ & 0.03 \\
\hline - Diffuso lowor limbs pain, $n(96)$ & $42(45.7)$ & $28(36.4)$ & 0.22 \\
\hline - Atypical polymyalgia theumatica, $n(96)$ & $30(53.6)$ & $13(38.2)$ & 0.15 \\
\hline - Hoadacho, n (\%) & $18(19.6)$ & $9(11.7)$ & 0.16 \\
\hline - Polymialgic syndrome, $n$ (\%) & $56(60.9)$ & $34(44.2)$ & 0.03 \\
\hline \multicolumn{4}{|l|}{ Laboratory markers at the time of requesting PET } \\
\hline - Anaemia, $n$ (96) & $18(20.2)$ & $22(28.9)$ & 0.19 \\
\hline - ESR $(m m / 1 \% h)$, meantSD & $43.3 \pm 34.3$ & $43.5 \pm 31.1$ & 0.72 \\
\hline - CRP (mg/al), median [IOR] & $0.9[0.3-2.6]$ & $0.9[0.3-2.5]$ & 0.54 \\
\hline \multicolumn{4}{|l|}{ Treatment at the time of requesting PET } \\
\hline - Pationts with corticostoroids, $n(\%)$ & $48(51.6)$ & $36(46.8)$ & 0.48 \\
\hline - Dasego of prodnisone (mg), modian [IOR] & $10[5-15]$ & $10[7.5-15]$ & 0.80 \\
\hline - Patients with traditional immunosupprossants, n (\%) & $11(12.0)$ & $5(6.5)$ & 0.21 \\
\hline
\end{tabular}

Conclusions: In this study, we have found that the presence of inflammatory low back pain and polymyalgic syndrome, especially in GCA patients, may have clinical relevance in ordering a PET/CT scan when aortitis was suspected.

Disclosure of Interest: None declared

DOI: 10.1136/annrheumdis-2017-eular.3368

\section{AB0585 VASCULITIS DAMAGE INDEX IN LIMITED AND SYSTEMIC GRANULOMATOSIS WITH POLIANGIITIS IN MEXICAN PATIENTS}

O. Vera-Lastra, A.G. Angulo-Gonzalez, J. Sepulveda-Delgado. Internal Medicine, Hospital Especialidades CMN la Raza. Instituto Mexicano Seguro Social, Mexico City, Mexico

Background: Granulomatosis with polyangiitis (GPA) has been transformed 